\title{
PRELIMINARY ANALYSIS FOR PLACE BRANDING AND PROMOTION OF THE WESTERN REGION OF SĂLAJ COUNTY, ROMANIA
}

\author{
Magor KÁDÁR \\ Faculty of Political, Administrative and Communication Sciences, Babeș-Bolyai University, Cluj-Napoca, ROMANIA \\ kadar.magor@fspac.ro \\ István BENEDEK \\ Faculty of Political, Administrative and Communication Sciences, Babeș-Bolyai University, Cluj-Napoca, ROMANIA \\ Benedek.istvan@fspac.ro \\ DOI: http://doi.org/10.23740/TID120193
}

\section{ABSTRACT}

The current paper is part of a detailed case study on the methodologies and practical procedures behind the tourism promotion of the Western region of Sălaj County in Romania. The aim of the paper is to offer insights regarding the identification of possible place identity elements in order to develop a future destination branding strategy for the region, opening the door for developing tourism promotion or place branding plans. The first part of the paper gathers data from the region by fieldwork and desktop research, then summarises the most important place identity elements of the region, while the second part lists the possible forms of tourism, applicable to the region and elaborates a real data-based source paper suitable to develop a detailed tourism promotion plan based on this research.

Keywords: destination branding, regional branding, place brand identity, tourism promotion

\section{INTRODUCTION}

Our case study highlights the most valuable natural and cultural values of the examined area that have tourism potential and may serve as a base for a future destination branding strategy of the region. Places have a certain identity that is constructed through historical, political, religious and cultural discourses; and also, through local knowledge (Govers and Go, 2009). This is true, even if there is no conscious attempt to develop a certain brand for the place in question. Place branding is always based on place identity elements that are able to differentiate a settlement, a region, or even a country from its competitors. These elements are the foundation of future branding strategies and can efficiently position a given place on the market. In this sense, the practice of place branding can be viewed as the art of distilling the essence of the place (Mayes, 2008). In order for these brand elements to work efficiently, places need to communicate these values in their promotional and communication activities. When a successful place branding strategy is implemented, both the internal (residents and local communities) and the external target groups (in our case, especially tourists and visitors) will be able to identify the given geographical area with these formulated and communicated brand values.

Our research focuses on a smaller part of the Transylvanian historical region of Romania. The examined area is part of the North-West Development Region, inside Sălaj County. From a geographical perspective, Sălaj County is located between the Apuseni Mountains (Munții 
Apuseni) and the northern part of the Eastern Romanian Carpathians (Carpații Orientali). The studied area is situated in the Western side of the Sălaj County and it has a territory of over 45,000 hectares. This territory encompasses a total number of eight communes and 32 villages. The eight communes situated inside the area are the following ones: Marca, Halmășd, Valcău de Jos, Crasna, Boghiș, Nușfalău, Plopiș, and Ip. Figure 1 provides a detailed overview of the examined region including the national, regional, and local level localization.

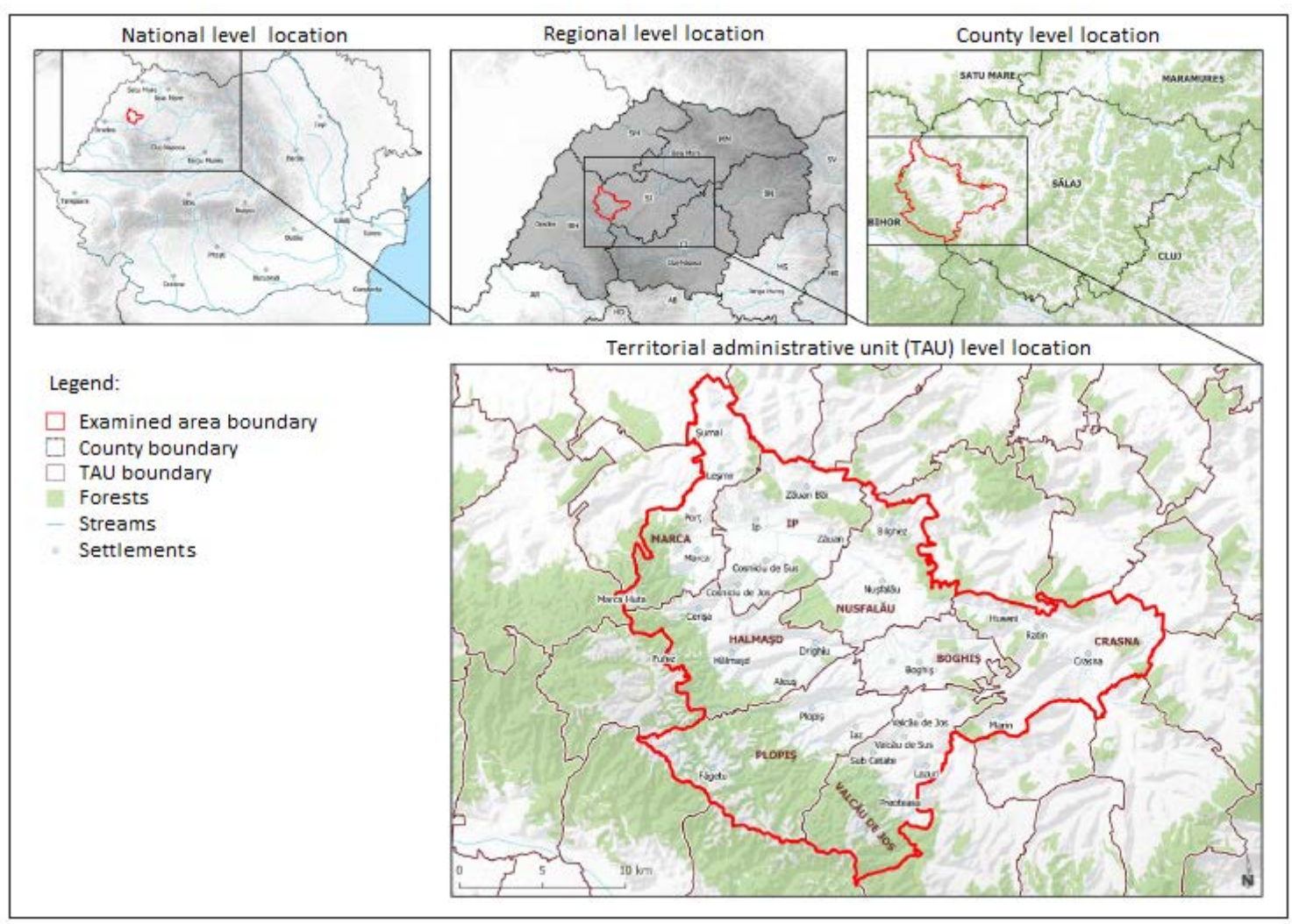

Figure 1: Geographical localization of the examined area

Source: Kovács et al., 2016, p. 5

(the Romanian variant was translated into English. No other changes were realised to the original maps)

\section{LITERATURE REVIEW}

Place branding is still considered a relatively new research field with multidisciplinary origins. The early academic interest came especially from the domains of urban policy, tourism and marketing (Hankinson, 2015). Since the beginning of the new millennium, there is a growing number of articles dealing with the concept of place branding and/or place marketing. The literature uses the terms place promotion, place marketing and place branding often as synonyms. However, we consider that a clear distinction should be made between these concepts. This distinction is explained in the work of Boisen (2015), who states that place promotion is about generating favourable communication, place marketing tries to balance the supply and the demand side, while place branding is about creating, sustaining and shaping a positive place identity. The development of this new research field is also marked by the 
appearance of the first dedicated journals and international conferences. The Journal of Place Branding and Public Diplomacy publishes its first volume in 2005, while the first international conference in destination branding is organised in the same year (Govers and Go, 2009, pp. 1516). More recently, 2016 saw the birth of the first dedicated association to the field, the International Place Branding Association (Govers et al., 2017).

The concept of place branding is an overarching term referring to the application of branding techniques at different scales of geographical areas. According to Braun (2011), place branding can be considered the family tree, with members such as nation branding, regional branding, city branding, location branding and destination branding acting as the branches of the tree. For the purpose of our study, it is essential to provide a clear definition for the concept of place branding and destination branding. Zenker and Braun (2010) are among the first authors to provide an encompassing definition for place brands. According to them, a place brand can be defined as "a network of associations in the consumers mind based on visual, verbal, and behavioural expression of a place, which is embodied through the aims, communication, values, and the general culture of the place" (Zenker and Braun, 2010, p. 5).

Place branding is always a strategic process because a certain place can influence its image through long-term commitment, clear directions and consistent communication (Benedek, 2017). In a place branding process, the main goal is to define a clear vision for the place, a recognizable, distinguishable and unique position compared to other places (Kádár, 2013). In other words, places can be differentiated through the process of branding. This differentiation occurs by choosing the right brand identity elements that are representative for the place. This is also illustrated in the definition of Anholt (2010), who states that place branding is the process of building a brand for a place that is based on the place's identity and on the formation of positive images in the minds of stakeholder groups.

There is a general agreement in the place branding literature that the process has three core target groups: local communities, tourists and investors. When the focus of these activities is centred on the tourist target group, destination branding is the term used to describe the process. In other words, using the term destination implies a tourism perspective for place branding strategies. One of the earliest definitions for the term destination brand is provided in the work of Ritchie and Ritchie (1998): "a destination brand is a name, symbol, logo, word mark or other graphic that identifies and differentiates the destination" (quoted in Kladou et al., 2017, p. 428). The process of destination branding is commonly understood as the communication of a distinctive and unique destination identity. Briciu (2013) quotes the report of World Tourism Organisation entitled Handbook on Tourism Destinations Branding, which states that destinations should focus on "seeking the essence that makes them different and attractive to visitors, and consistently promote this essence through all marketing communications and behaviour. Over time this will help the destination gain a consistent reputation, based on these brand values".

The process of destination branding can be divided into five consecutive phases: (1) market investigation, analysis and strategic recommendations, (2) brand identity development, (3) brand launch and introduction consisting in communicating the vision, (4) brand implementation, and (5) monitoring, evaluation and review (Morgan and Pritchard, 2004, p. 69). The current paper focuses on the first stage of the process. It summarises the market investigation and analysis and formulates some strategic recommendations for the future destination branding of the selected region. 


\section{METHODOLOGY}

In order to determine potential place identity elements, we used the results of a preliminary study (Kádár, 2016), which analysed the media and online image of the area, evaluated the documents referring to the development of the region and summarised several stakeholders' opinions (i.e. a total number of 12 opinion leaders from the local communities, including mayors, school teachers, leaders of the cultural institutions) about the local communities. In addition, we carried out five interviews with experts involved in the project. The interviews took place from the $3^{\text {rd }}$ to the $6^{\text {th }}$ of February, 2016. Methodologically, they were semistructured interviews of a blended genre. For each working group, we inquired about their experience related to the work conducted in the area and we also asked them about the most important benefits and drawbacks of the researched area in their opinion, as viewed from the perspective of their area of expertise.

\section{EXPLORING PLACE IDENTITY ELEMENTS WITH TOURISM POTENTIAL}

Based on the results of our research, we determined the following potential place identity elements, which can serve as a basis for future place branding or destination branding strategies as listed in Table 1. For a better transparency, we set up several groups and gave a separate description for each group.

Table 1: Potential place branding elements of the researched area

\begin{tabular}{|l|l|}
\hline Architectural heritage & Settlements \\
\hline Bánffy Castle and manor & Nușfalău \\
\hline Medieval churches & Crasna, Nușfalău \\
\hline Wooden church & Porț (Marca) \\
\hline Ruins of Valkó Fortress & Valcău de Jos \\
\hline Natural heritage & Nușfalău \\
\hline The Lapiș forest & Plopiș \\
\hline The Plopiș wetland & Nușfalău, Cerișa, Cosniciu de Jos, Cosniciu de Sus \\
\hline Wood pastures & Valcău de Jos, Halmășd, Plopiș \\
\hline The Plopiș Mountains & \multicolumn{2}{|l|}{} \\
\hline Anthropic elements & Crasna \\
\hline The water reservoir in Vârșolț & Boghiș \\
\hline Healing thermal springs & \multicolumn{2}{|l|}{} \\
\hline Famous personalities & Crasna \\
\hline Farkas Cserey (botanist) & Crasna \\
\hline Maxim Aurel (horticulturist) & Nușfalău \\
\hline János Arany (poet) & Nușfalău \\
\hline György Ruzitska (composer) & Valcău de Jos \\
\hline Camelia Corina Burghele (etnographer) & Valcău de Jos \\
\hline Viorel Ispas (engineer, professor) & \multicolumn{2}{|l|}{} \\
\hline
\end{tabular}




\begin{tabular}{|l|l|}
\hline Vladimir Pop Mărcanu (writer) & Marca \\
\hline Viski János (composer) & Zăuan \\
\hline Local gastronomy & Marca \\
\hline Pancakes & Nușfalău \\
\hline Mushrooms & Valcău de Jos \\
\hline Honey & Crasna, Zăuan, Boghiș, Bilghez, Leșmir \\
\hline Wine & Crasna, Boghiș \\
\hline Brandy & \multicolumn{2}{|l|}{} \\
\hline Local events & Nușfalău \\
\hline Arany János Days & Nușfalău \\
\hline Bánffy György Days & Marca \\
\hline Pancake festival & Crasna \\
\hline Wine competition and men's day & Ip \\
\hline Bread baking day - harvest day & Nușfalău \\
\hline Butchers' competition & Făgetu \\
\hline Village day & \multicolumn{2}{|l|}{} \\
\hline Local traditions & $\begin{array}{l}\text { Crasna, Boghiș, Nușfalău, Zăuan, Bilghez, } \\
\text { Leșmir }\end{array}$ \\
\hline Wine making and wine cellars & Crasna, Nușfalău, Ip, Valcău de Jos \\
\hline Folk dancing and music & Plopiș, Crasna \\
\hline $\begin{array}{l}\text { Ethnographic museums and local } \\
\text { collections }\end{array}$ & Crasna, Nușfalău \\
\hline Traditional markets &
\end{tabular}

Source: Based on the research conducted in the area.

\section{Architectural heritage}

The Bánffy Castle and manor in Nușfalău were built at the end of the $18^{\text {th }}$ century. The buildings housing the bailiff and servants' apartments, the barns and stables survived and are part of the complex. A second, less impressive castle belonging to the Bánffy family, is situated in Boghiș.

An outstanding piece of the architectural heritage is the Protestant church in Crasna, one of the most important medieval buildings in Sălaj region. The most spectacular component of the church is its painted coffered ceiling, featuring a number of figurative and zoomorphic representations, as well as several biblical scenes. The building is a distinctive, impressive sight from the outside and it may serve as a characteristic visual element of the region. The other important medieval construction of the region is situated in Nușfalău and, besides the Reformed church in Tășnad, is the largest medieval building in Sălaj region. The church hosts the only well preserved medieval mural painting of Sălaj region.

Another characteristic construction of the region is the wooden church in Porț, the most important architectural piece of Marca, the interior of which is richly decorated with painted biblical scenes and a set of old icons. Although the architectural heritage of the Orthodox 
community from Sălaj includes many wooden churches, the one in Porț is the only well preserved edifice that has survived to the present day. An important piece of the architectural heritage of the region is the fortress in Valcău de Jos, dating back to the $13^{\text {th }}$ century and situated on the top of a hill, above the settlement.

\section{Natural heritage}

An outstanding site of natural heritage is the Lapiș forest which preserved the rich vegetation once characteristic for Sălaj region (mentioned as "Terra Ultra Sylvania", in ancient documents). This natural protected area is situated south of Nușfalău, has an extremely rich vegetation and fauna and serves as a habitat for 25 protected bird species. Right outside the forest, there are three small ponds, too.

The Plopiș wetland is situated on the edge of the eponymous village and it is a peatbog declared a protected area in 2000. The main attraction of the bog is the "insectivorous" Drosera rotundifolia, an ice age relict plant.

In the vicinity of Nușfalău, Cerișa, Consniciu de Sus, Consniciu de Jos and Hosniciu, there are a series of wood pastures with oaktrees several hundred years old, some of them present in the area since the $1700 \mathrm{~s}$. These oak forests are populated by rare, protected insects such as the stag beetle or the great Capricorn beetle, species considered extremely rare in the western part of the European continent. The Plopiș Mountains are a protected Natura 2000 site, situated between Sălaj and Bihor Counties, popular especially among local hikers.

\section{Anthropic elements}

The water reservoir in Vârșolț, not yet declared a protected area, boasts a very rich bird fauna, too. Another important natural heritage of Sălaj region is its set of healing thermal waters. There is a popular thermal water spa in Boghiș and several others are being built in Boghis and Nușfalău. According to the testimony of several ancient documents, the healing waters of Zăuan had once been among the best such assets in Hungary, but the spa was closed down long ago.

\section{Famous personalities born in the area}

One of the most famous personalities from this region is Farkas Cserey, a celebrated Transylvanian botanist born in Crasna, who established the very first Transylvanian botanical garden in his hometown. Owing to a series of floods and the disinterest of successors, the garden later disappeared. In 2003, the people of Crasna commemorated his name with a memorial tablet.

Another famous personality of Crasna is the horticulturist Aurel Maxim, researcher and professor at the University of Agricultural Sciences and Veterinary Medicine in Cluj-Napoca, author of more than 150 articles published in different Romanian and foreign journals, a scientist who discovered several types of fruit-tree viruses.

The famous Hungarian poet, János Arany's name may also be linked to the researched area, as his parents were said to be born in Nușfalău and his most widely read work, Toldi, is also linked to this region. There are no documents supporting these claims but the memory of the poet is 
kept alive by locals: they are organising the Arany János Days on a yearly basis and the local library and park bear the name of the poet as well.

The Hungarian composer and pianist György Ruzitska arrived to Nușfalău, Transylvania, in 1810, after completing his studies in Vienna and became a private tutor to the Bánffy family. The ethnographer and museologist Camelia Corina Burghele was born in Valcău de Jos, and so was Viorel Ispas, professor of architecture at the Technical University of Cluj-Napoca, with over 100 papers published, a holder of four patents, and an innovation. In Marca, a settlement in the researched region, studied the Romanian writer Vladimir Pop Mărcanu, active between the years 1981 and 2008. The Kossuth prize winner composer, János Viski, was also born in Zăuan and after completing his studies he returned to live and work in his hometown.

\section{Local gastronomy}

Based on our research, the traditional pancakes from Marca, the wine from Crasna, the mushrooms from Nușfalău, the honey from Valcău de Jos and the plum brandy from Boghiș and Crasna have the strongest gastronomic potential of the region. The local pancake festival is an event held during the village days of Marca. The rolling hills and warm climate of Sălaj region are great for vineyards and winemaking and the latter is characteristic for the whole region. Within the researched region, we can find wineries especially in Crasna, Boghis and around Zăuan. Rows of wine cellars carved into the sandstone of the hillsides could become an important tourism attraction. We found more such rows of cellars in Leșmir and Bilghez, but these are in a rather bad condition. Zăuan has a unique site of three rows of wine cellars with a strong tourism potential, as it could easily act as an attraction for visitors.

The wild mushrooms growing around Nușfalău may be of gastronomic interest while one of the largest mushroom production plants in Romania, the Boglár Champ, is also situated in this area. Mushroom production is an important part of the local economy and may become an export brand of the region, while mushrooms may become a valuable element of gastronomic events held in the region.

The honey produced in Valcău de Jos has recently been praised by the botanist of the British royal family; honey mixed with slices of birch mushroom is a local speciality featured in 2012 at the International Food Exhibition in Paris. Honey, sold not only locally, but also through online trade, reaching Western European consumers, could be an important brand of the region, too.

Plum brandy is produced and bottled especially in Boghiș and Crasna, but the tradition of brandy making is at home in the entire region. Opposite to wine making mainly practiced in Hungarian communities, brandy is produced both by the Romanian and Hungarian communities. One of the most important distilleries in the region was owned by the Bánffy family and used to operate in Nușfalău. Nowadays the building is deserted but it could be restored with an infusion of funds and it could function again.

\section{Local events with tourism potential}

The most important events in the region are the Arany János and Bánffy György Days (formerly St. George Days) in Nușfalău and the Pancake Festival in Marca. The Arany János Days are organised in October by the local administration, the Reformed Church, and the local school. The event lasts two days and consists of folk dance performances, various competitions and recitation of poetry. The Bánffy György Days are organised yearly, in April, by Bánffy György 
Cultural Foundation. The programme includes folk dance parties, a cooking competition and other cultural and sports events. The Pancake Festival in Marca was first organised in 2011 as part of the cultural days of the local community. These are mainly local events, so the focus of target groups is on local community, however, some of them may possess potential to attract visitors and tourists as well.

Crasna was once famous for its Wine Festival, but nowadays they organise only one event, the wine competition included in the programme of the local Men's Day. Harvest Day is an opportunity to present traditional crafts and customs. Such an event was organised in Ip only once, but there are plans, according to our research, to turn it into a regular series. A similar event, organised for the second time is the Butchers' Competition in Nușfalău. A peculiar one among the village days organised in the region, is the Village Days in Făgetu, a great opportunity for the local Slovak minority to present their values and traditions to the wider public.

\section{Local traditions}

Viticulture and wine making are two of the most important traditions in the region. Unfortunately, the number of grape and wine producers constantly drops. At the same time, there is a perceptible effort to re-introduce old, traditional Transylvanian varieties of vine like bakator or an old Portughese vine called oportó.

Beside viticulture and wine making, singing and folk dance are strong traditions in the region. Many villages have their own folk dance groups (i.e. Gyöngyösbokréta group in Crasna, the Vadrózsák and Kéknefelejcs in Nușfalău, the Mákvirág in Ip, and the Ciberke in Zăuan) and folk dance performances are usually featured in the programme of every local event. Folk dance and arts and craft camps are regularly organised in Crasna and Boghiș.

We may find small ethnographical museums or collections in most of the villages, but there are only very few settlements where they pay real attention to these collections and they are presented to the public, too. The most interesting and unique ethnographical museum of the region is situated in laz (close to Plopiș). Ligia Bodea started it at the age of 12, when she decided to turn the house of her grandparents into an ethnographical collection, thus becoming the youngest collector of the country. With its three ethnographical museums and collections, laz is the most peculiar settlement of the region. Another important collection is that of the Ethnographic Museum in Crasna. Smaller collections are also to be found in Marca and Șumal, Halmășd and Aleuș, Ip, Valcău de Sus and Valcău de Jos, as well as in Nușfalău, where the collection belongs to the Torkos and Posta families.

\section{IDENTIFYING CRITICAL ELEMENTS}

A general characteristic of the studied region is that it has failed at exploiting the tourism potential of its natural and cultural values. There are several reasons for that, to be discussed in more detail within this chapter. In determining critical elements, we relied on the conclusions of our first study (Markó et al., 2016) and on the results of the interviews conducted with leading experts of working groups. We paid special attention to identify problems mentioned in the actual regional (Agenția de Dezvoltare Regională Nord-Vest, 2014), county level (Development Strategy of Sălaj County 2014-2020) or local (Local Development Strategy for 2014-2020 of the Nușfalău Territory, Sălaj County) development plans. The critical elements are summarised within Table 2. 
An important problem concerning the architectural heritage is the current condition of the buildings. If the aim is to attract more visitors, castles and manors in the region should be restored to their original beauty. As most of these buildings are not to be found on the national list of protected monuments, it is quite difficult to find necessary funding for their renovation. A similarly important problem is that there are very few events organised in or around these buildings. In order to increase their tourist potential, it is recommended to use castle and manor buildings as a venue for cultural and recreational events.

Table 2: The critical elements of the studied region from the point of view of settlement branding

\begin{tabular}{|c|c|}
\hline Tourism key elements & Critical elements \\
\hline $\begin{array}{l}\text { Architectural } \\
\text { heritage }\end{array}$ & $\begin{array}{l}\text { The majority of the architectural sites are not included } \\
\text { on the national list of protected monuments; } \\
\text { Most of the architectural sites are in bad condition; } \\
\text { Lack of events and programmes related to these } \\
\text { architectural sites (i.e. castles and manors). }\end{array}$ \\
\hline Natural heritage & $\begin{array}{l}\text { Low number of protected areas; } \\
\text { Lack of marked hiking tracks; } \\
\text { Need to raise awareness of values within local } \\
\text { communities. }\end{array}$ \\
\hline $\begin{array}{l}\text { Local } \\
\text { gastronomy }\end{array}$ & $\begin{array}{l}\text { The once popular wine production gradually loses } \\
\text { emphasis; } \\
\text { Most of the products are made only for personal use; } \\
\text { Available products are not marketed and } \\
\text { communicated properly. }\end{array}$ \\
\hline Events & $\begin{array}{l}\text { Lack of events involving masses of people. Most } \\
\text { events are focused exclusively on local communities; } \\
\text { No proper synchronization regarding the calendar of } \\
\text { local and regional events. }\end{array}$ \\
\hline $\begin{array}{l}\text { Local traditions } \\
\text { and crafts }\end{array}$ & $\begin{array}{l}\text { Number and condition of traditional houses; } \\
\text { Need to raise awareness of values within local } \\
\text { communities. }\end{array}$ \\
\hline $\begin{array}{l}\text { Tourism } \\
\text { infrastructure }\end{array}$ & $\begin{array}{l}\text { Low number of places offering accommodation; } \\
\text { Lack of marked bicycle trails and hiking paths; } \\
\text { Tourism related services are non-existent or } \\
\text { undeveloped. }\end{array}$ \\
\hline $\begin{array}{l}\text { Tourism } \\
\text { communication }\end{array}$ & $\begin{array}{l}\text { Tourism communication at regional level (i.e. Sălaj } \\
\text { County) pays little attention to the studied area; } \\
\text { Lack of a comprehensive tourism promotion strategy } \\
\text { that takes into account the whole region. }\end{array}$ \\
\hline
\end{tabular}


There are three natural reserves within the studied area (the Plopiș Mountains, the Lapiș Forest and the Wetland in laz). It would be recommended to turn several other areas into natural reserves: the wood pastures around Nușfalău, Cerișa, Cosniciu de Sus, Cosniciu de Jos and Huseni, and the water reservoir in Vârșolț and its surroundings. In our opinion, local communities are not always aware of the values surrounding them, regardless of their cultural or natural character. Among the most important features of the region are these rich, untouched habitats demanding attention and care. In order to harness their tourist potential, it is recommended to develop a series of hiking trails and to provide them with information panels.

From the gastronomic point of view, the oldest tradition in the region is wine making. There are less and less wine producers in the region and even the remaining ones are lacking the necessary infrastructure to properly bottle and label their products and also there are no proper conditions for wine bottling within small wineries. For this particular reason, every year, many thousand litres of quality wine are treated as industrial alcohol. The measures necessary for the reviving of local wine making traditions would be: to offer producers municipal financing, to familiarise them with tenders and teach them to submit applications, to organise traditional fairs and gastronomic events within the region, to found an organisation for producers, to establish links and cooperation with other domestic and foreign producers.

Beside grapes, there are many other types of fruit produced in the region and harnessing this potential could be another option for locals. Our experience shows that the local population makes jam, fruit juice and brandy for private use, and there is no organisation to gather local producers, support processing and provide marketing opportunities. The already existing local products have rather poor presence on the market. The mushroom of Nușfalău and the honey of Valcău de Jos deserve to be much more popular than they currently are, and there should be events organised about them.

Regarding the events organised in the region, the biggest problem is that they are not able to reach a wider target group and they focus mainly on the population of a particular settlement and a few others from the surroundings. The existing events should be synchronised so that they follow each other without long gaps, and fill the existing gaps with new events. It is recommended to support the events by promoting local values and products, like the Honey Days of Valcău de Jos, the Mushroom Festival and Traditional Fair of Nușfalău, The Fair and Wine Festival of Crasna.

A critical element of the preservation of local traditions is the condition of traditional buildings. We have already mentioned the locals' lack of awareness regarding the values surrounding them. Traditional folk costumes are currently worn only at local events, while traditional houses and barns are often in deplorable condition and serve no purpose at all.

One of the most serious problems regarding tourism infrastructure is the lack of accommodation. Accommodation facilities in the studied area are discussed in detail within the next part of the paper. The lack of such facilities indicates that organised tourism is rather scarce in the region. Therefore, to better exploit the tourism potential in the region, we recommend a thorough development of tourism infrastructure, by introducing accommodation and catering facilities, marked hiking and cycling trails, information boards, etc.

In the previous section, we touched upon the lack of tourism promotion. The general picture based on our research indicates that the examined region is not considered an important tourism destination and it does not have a well-structured strategy for tourism related promotion. Current communication of the region does not match in highlighting main tourism attractions and available tourism services of any given settlement. Settlements have neither 
distinctive brand identity (like tourism related logos, slogans and formulated messages), nor well defined pillars to eventually support such an identity. The information provided by tourist information offices is usually of poor quality, out of date and missing the point (e.g. what accommodation facilities are available for those visiting the region).

\section{DEVELOPING A TOURISM PROMOTION PLAN}

This part presents the main elements of tourism infrastructure within the region: accommodation and catering facilities, information services and other local tourism establishments.

\section{Accommodation and catering}

According to the data provided by the National Authority for Tourism (Ministerul Turismului, 2019), there is a total number of 86 authorised accommodation facilities in Sălaj County. Out of these facilities, only 16 (about 18\%) are located in the researched area. These facilities are concentrated in the Commune of Boghis ( $81 \%)$, while the remaining three facilities are situated in Crasna and Ip communes (Table 3).

Table 3: Accommodation facilities in Sălaj County by type and location

\begin{tabular}{|l|l|l|}
\hline $\begin{array}{c}\text { Accommodation } \\
\text { name }\end{array}$ & \multicolumn{1}{|c|}{$\begin{array}{c}\text { Accommodation } \\
\text { type }\end{array}$} & $\begin{array}{c}\text { Accommodation } \\
\text { location }\end{array}$ \\
\hline Aromă de Primăvară & Touristic pension & Boghiș \\
\hline Boghiș & Touristic pension & Boghiș \\
\hline Casa Albă & Agrotouristic pension & Boghiș \\
\hline Casa Grande Boghiș & Rooms for rent & Boghiș \\
\hline Cristal & Agrotouristic pension & Boghiș \\
\hline David & Rooms for rent & Boghiș \\
\hline Oazis & Bungalow & Boghiș \\
\hline Renata & Agrotouristic pension & Boghiș \\
\hline Imola Residence & Rooms for rent & Boghiș \\
\hline Imola Residence & Camping & Boghiș \\
\hline Cetatea & Agroturistic pension & Boghiș \\
\hline Flori de Tei & Bungalow & Boghiș \\
\hline Trifoiaș & Touristic pension & Boghiș \\
\hline Rin & Camping & Crasna \\
\hline Trans Bitum & Hotel & Ip \\
\hline Trans Bitum & Hostel & Ip \\
\hline
\end{tabular}


Further accommodation options for tourists visiting the region: pensions in nearby towns like Șimleu Silvaniei (six accommodation facilities), which is situated at about $10 \mathrm{~km}$ distance from the examined area. Another option is the seat of Sălaj County, Zalău (about $25 \mathrm{~km}$ from the examined area), which offers 16 accommodation facilities for visitors, including four stars rated hotels like Grand Hotel Severus or Griff Hotel. According to the statistics of the National Authority for Tourism (Ministerul Turismului, 2019), there is a total number of 50 touristic facilities with catering options in Sălaj County. Out of these facilities, $11(22 \%)$ are located within the studied area. These facilities are concentrated in two communes: Boghiș (7 facilities) and Ip (4 facilities).

Table 4: Touristic facilities with catering within the studied area

\begin{tabular}{|l|l|l|}
\hline \multicolumn{1}{|c|}{ Place name } & Place type & Place location \\
\hline Aromă de Primăvară & Bar & Boghiș \\
\hline Aromă de Primăvară & Restaurant & Boghiș \\
\hline Capricorn & Bar & Boghiș \\
\hline Capricorn & Restaurant & Boghiș \\
\hline Casa Renata & Bistro & Boghiș \\
\hline Palmier & Restaurant & Boghiș \\
\hline Satelit & Snack-Bar & Boghiș \\
\hline Grand Imperio & Restaurant & Ip \\
\hline Nufărul & Restaurant & Ip \\
\hline Orhideea & Restaurant & Ip \\
\hline Orhideea & Bar & Ip \\
\hline
\end{tabular}

Source: Data from the National Authority for Tourism (turism.gov.ro).

Table 4 summarises the touristic facilities with catering options within the examined area. Our field research demonstrated that there are some facilities in Nușfalău commune as well. The village of Nușfalău provides two classic restaurant options for visitors (Daya Ambient and Grossman) and two pizza places (Rustiq Pizza and Dragon Pizza).

\section{Tourist Information Offices}

Tourist Information Offices of the region were established with support from the Ministry of Agriculture and Rural Development (Ministerul Agriculturii și Dezvoltării Rurale) through the AFIR, the Agency for Rural Investment Financing (Agenția pentru Finanțarea Investițiilor Rurale). Such offices were established in five out of the eight communes of the studied area as listed in Table 5, below.

The Tourist Information Offices of Valcău de Jos and Crasna communes have their own personalised visual identity. The information posted on the mentioned websites (Table 5) is usually available only in Romanian, the only exception is the website of the Tourist Office in Nuşfalău, where the content is available in three languages (Romanian, Hungarian, and English). Accommodation and catering facilities in the given area are usually listed on these websites (excepting the sites of Valcău de Jos, Plopiș and Crasna). Only one webpage, the one 
of Valcău de Jos mentions no local events at all, nevertheless none of the webpages contain a comprising event calendar. The webpage of Valcău de Jos commune is the only one to include community media content. We were informed that a Tourist Information Office will soon be opened in Boghiş as well.

Table 5: Tourist information offices operating within the studied area

\begin{tabular}{|l|l|}
\hline $\begin{array}{l}\text { Name of the } \\
\text { commune }\end{array}$ & $\begin{array}{l}\text { Website of the local Tourist } \\
\text { Information Centre (TIC) }\end{array}$ \\
\hline Halmășd & $\underline{\text { www.turismhalmasd.ro }}$ \\
\hline Plopiș & $\underline{\text { www.centruturisticplopis.ro }}$ \\
\hline Crasna & $\underline{\text { www.turismcrasna.ro }}$ \\
\hline Nușfalău & $\underline{\text { www.centruturisticnusfalau.ro }}$ \\
\hline Valcău de Jos & $\underline{\text { www.turismvalcaudejos.ro }}$ \\
\hline Marca & - \\
\hline Ip & - \\
\hline Boghiș & - \\
\hline
\end{tabular}

Source: Based on the conducted research.

\section{Directions for tourism development}

\section{Cultural and heritage tourism}

Heritage tourism is part of cultural tourism. It can be defined as it follows: "From a comprehensive point of view cultural tourism is a touristic product. Its central element is attraction which satisfies the intellectual needs of the tourist. From a more restricted point of view cultural tourism is a culturally motivated travel: a visit to monuments, heritage sites, museums, participation at festivals, exhibitions, theatre or musical performances, study trips or pilgrimages" (Michalkó and Rátz, 2005, pp. 164-165), while the heritage tourism is "tourism based on heritage, in the case of which heritage is primarily the central element of the product and the main motivation for tourists" (Swarbrooke, 1994, p. 70).

Current situation: Upper class mansions - such as the Bánffy Castle and manor in Nușfalău and Boghiș and churches like those in Crasna and Nușfalău, or the wooden church in Porț - belong to the architectural heritage with the highest tourist potential within the studied region. The buildings belonging to the Bánffy family require substantial renovation, they cannot be considered genuine tourist attractions in their present state. The renovation of many buildings in the architectural heritage of the region is difficult because the said buildings do not appear on the list of national monuments.

Our recommendation: Every item of architectural heritage carrying an important tourist potential should appear on the list of national monuments. Mansions belonging to the Bánffy family ought to be renovated, opened to the public and they should serve as venues for regular cultural events. Within the studied region, there are several castles, mansions and manors which would be worth visiting during organised sightseeing tours: i.e. Báthory Castle (Șimleul Silvaniei), Károlyi-Dégenfeld Castle (Balc), Bay Castle (Treznea), Wesselényi Castle (Jibou), Károlyi Castle (Carei), Teleki Castle (Coltău), Ardud Fortress (Ardud), Bánffy castle (Bonțida), and Bánffy Castle (Răscruci). 


\section{Event tourism}

A type of tourism regarding events organised in a given region as a tourist attraction, while events have an image building role (Getz, 2008). Event tourism used to be considered a branch of other types of tourisms (profession tourism - conferences, sports tourism - international events, cultural tourism - festivals, concerts), but nowadays it is already treated as a separate type.

Current situation: The events of the studied region cannot address large target groups; they focus only on the population of the settlement where they take place. Events focusing on the characteristics of the region and the peculiar values of a given settlement are rare.

Our recommendation: The existing events should be promoted more intensely and neighbouring settlements should be included, too. A series of new events focusing on local values should be organised, e.g. a Mushroom Festival in Nușfalău, Honey Days in Valcău de Jos, traditional fairs in Crasna and/or Nușfalău, a Harvest Day Ball and a Wine Festival in Crasna. The existing events should be synchronised with future ones, so that visitors in the region to have always an event to go to.

\section{Rural tourism}

In a more restricted sense, rural tourism is a way by which families living in the countryside make an extra income, while, in a wider sense, it includes all the tourist activities of the region. In this study, we prefer the stricter sense only, according to which rural tourism designates the trend of village people making an extra income beside their main profession (agriculture, industry), by renting out their extra rooms or accommodation facilities to vacationers (Csizmadia, 1993).

Rural tourism usually includes all services, from accommodation and catering to organised programmes. In rural tourism, the use of private estates for tourist purposes is combined with the presentation of the rural environment and lifestyle. In rural tourism, visitors may get an insight into rural lifestyle, local crafts, customs and traditions, taste the local dishes and beverages. Visitors may also take part in diverse agricultural activities or work around the house (Michalkó, 2004).

Current situation: The studied region may be interesting for visitors owing to its untouched character: the entire area has preserved a natural, archaic environment. The majority of the old, traditional houses are deserted or in a very bad condition, which makes the development of rural tourism more difficult. Another question is the willingness of locals to get involved in such activities. Currently, the opportunities of rural tourism are left unexploited in all settlements in the region.

Our recommendation: Rural tourism requires proper accommodation and catering conditions and recreational activities organised for the visitors as well as various communication channels necessary for the promotion of services.

\section{Gastro-tourism}

Gastro-tourism is travel aimed at discovering the gastronomical values of a certain area (Bujdosó, Kerekesné, and Ujvári, 2012). This type of tourism focuses on getting acquainted with the culinary values of a given area, on the tasting of characteristic dishes and beverages, and on attending gastro festivals. 
Current situation: Gastro-tourism is closely related to rural tourism (tasting traditional dishes and beverages) and event tourism (gastronomic events). From the point of view of gastrotourism, there are no local specialties in the region, but there are a few local products, e.g. mushrooms, honey, pancakes, which could serve as a starting point in this respect.

Compared to foods, local beverages have a more substantial tradition because the greater part of the region used to be famous for its wines. Within the studied region, Crasna boasts a long tradition in wine making and there are different events related to wine and wine making in the settlement. Zăuan, Nuşfalău, Boghiş, Leşmir and Bilghez are also well known for their vineyards. Unfortunately, less and less locals are dealing with viticulture and wine making, most of the wine cellars of Leşmir and Bighez are deserted and empty. A general problem for the producers is that they do not have the necessary infrastructure to bottle and label their products and they do not have the necessary know-how to bottle them in small wineries.

Our recommendation: The quality of the wines is good enough to build wine tourism upon it. But in order to be promoted as a wine producing area, the region needs properly bottled and labelled wine and varied opportunities through which this type of tourism can be promoted: organised visits to various wine cellars, wine tasting events in local cellars and castles, wine evenings or balls in old mansions, the development of a wine route, and wine and vintage festivals. Peculiar rows of wine cellars may be a good venue for developing wine tourism. In order to exploit their tourist potential, these rows of wine cellars should be interlinked and integrated into a wine route with a series of various events organised in or around them.

\section{Ecotourism}

The most common forms of ecotourism are hiking and walking, but this type of tourism also includes visiting caves, mountain climbing, cycling, horse riding, paddling, and skiing. Ecotourism is a very mild type of tourism which facilitates a better understanding between visitors and the local population, it does not represent a threat to the cultural features of the visited area and has a low impact on the environment (Tasnádi, 2002). Classical ecotourism means visiting "undisturbed" or pristine nature, where visitors may observe different animal and plant species, the phenomena and processes of nature. Ecotourism is similar to nautical, cycling, fishing or hunting tourism and is an active type of tourism (Michalkó, 2004).

Current situation: The relatively untouched landscape and the preserved natural sites and values make the studied region appropriate for ecotourism. The problem is that the most important natural sites are not promoted and presented to visitors. There are no information boards, marked hiking trails or auxiliary services supporting ecotourism (e.g. bike rental services) at all and there are no tour guides to accompany tourists on these paths.

Our recommendation: It consists of presenting the natural sites and values, posting information boards, marking out camping sites, developing marked hiking trails and cycling paths, and setting up tree-stands and places for animal observation. There are several important areas from the point of view of ecotourism: the wetland of laz, the Plopiş Mountains, the Lapiş forest, oak tree pastures, the surroundings of the Vârşolţ water reservoir where, besides fishing piers, bird watching stands should also be set up.

\section{Health and wellness tourism}

In health and wellness tourism the primary motivation of the travel is to preserve and improve one's health. We may speak of health or wellness tourism depending on whether the central 
element is healing or prevention. Health tourism is based on the use of certain services related to various forms of therapy, usually based on a natural element like thermal water, healing water, ooze or a certain type of post-volcanic activity. Thermal tourism is an important segment of health tourism, where the tourist product is based on healing waters, with a temperature over $30^{\circ} \mathrm{C}$ (Michalkó, 2004).

Current situation: Although there are several hot water springs in Nuşfalău and Zăuan, for the moment there is only one spa - the one in Boghiş - available for those interested in health and wellness tourism. The thermal water of Boghiş is good for treating neurological, rheumatic, and gynaecological problems. The spa has an outdoor and indoor pool for health and recreational purposes and offers physiotherapy (hydro-, balneo-, thermo-, fito- and mechanotherapy) as well. Most of the critical remarks concerning the thermal spa refer to an inadequate price-value proportion.

Our recommendation: The health and wellness tourism of the region may be further developed by exploiting these natural sources more efficiently. It would be good to study the area of Zăuan for establishing a second spa, because these waters used to be the best in Hungary. In the case of the spa in Boghiş, it would be recommended to develop a competitive price for visitors because most complaints refer to the inadequate proportion of price and quality.

\section{Defining target groups and main communication channels}

In this part, we make a few recommendations as presented in Table 6, to the already defined forms of tourism, by taking into account possible target groups and communication channels. In the previous part, we defined six types of tourism that, in our opinion, are the most suitable for the studied area.

Table 6: Target groups according to type of tourism and proposed communication channels

\begin{tabular}{|c|c|c|}
\hline Type of tourism & Target groups and characteristics & Communication channels \\
\hline $\begin{array}{l}\text { Cultural and } \\
\text { heritage } \\
\text { tourism }\end{array}$ & $\begin{array}{l}\text { Domestic and foreign tourists } \\
\text { domestic: especially Transylvania } \\
\text { foreign: Hungary (high priority target), } \\
\text { France, Germany, Spain, Italy, United } \\
\text { Kingdom } \\
\text { organised form } \\
\text { group travel } \\
\text { by coach }\end{array}$ & $\begin{array}{l}\text { Domestic tourists } \\
\text { webpage (tourist page run } \\
\text { by the County Council and } \\
\text { tourist information pages } \\
\text { run by local councils) } \\
\text { Facebook page (the page of } \\
\text { Sălaj and those of the } \\
\text { settlements) } \\
\text { Tourist Offices in the } \\
\text { region and the county } \\
\text { search engine keyword } \\
\text { optimisation (SEO) } \\
\text { Foreign tourists } \\
\text { website } \\
\text { Facebook page } \\
\text { Participation at tourism }\end{array}$ \\
\hline
\end{tabular}




\begin{tabular}{|c|c|c|}
\hline & $\begin{array}{l}\text { They are interested in Transylvanian } \\
\text { history; therefore, the primary target } \\
\text { group are Hungarian speaking tourists. }\end{array}$ & $\begin{array}{l}\text { fairs (Sălaj region) } \\
\text { search engine keyword } \\
\text { optimisation (SEO) }\end{array}$ \\
\hline Event tourism & $\begin{array}{l}\text { Domestic tourists } \\
\text { domestic: Sălaj County (and the } \\
\text { neighbouring ones) } \\
\text { relatives visiting their family } \\
\text { not an organised form } \\
\text { They arrive with the family or in small } \\
\text { groups, usually by their car. } \\
\text { They visit the region during the event. } \\
\text { Their accommodation is not necessarily } \\
\text { within the region. They prefer to stay } \\
\text { with family or friends. } \\
\text { The event should be interesting enough } \\
\text { for them to visit the region or to plan } \\
\text { their visit for the date of the event (family } \\
\text { visiting). }\end{array}$ & $\begin{array}{l}\text { Domestic tourists } \\
\text { website } \\
\text { Facebook page (event) } \\
\text { public place (plakát) } \\
\text { informal channels (word of } \\
\text { mouth) }\end{array}$ \\
\hline Rural tourism & $\begin{array}{l}\text { Foreign tourists: France, Germany, Spain, } \\
\text { Italy, United Kingdom, Hungary } \\
\text { Middle age couples or smaller groups } \\
\text { (younger people), urban environment } \\
\text { Explorers who would like to discover the } \\
\text { traditions and everyday life of the region; } \\
\text { they do not only want to rest, but seek } \\
\text { active relaxation. } \\
\text { Their visit is longer, they are } \\
\text { accommodated in village houses and eat } \\
\text { there, too. }\end{array}$ & $\begin{array}{l}\text { Foreign tourists } \\
\text { website } \\
\text { Facebook page } \\
\text { touristic fairs } \\
\text { catalogues } \\
\text { leaflets } \\
\text { search engine keyword } \\
\text { optimisation (SEO) }\end{array}$ \\
\hline $\begin{array}{l}\text { Gastro- and } \\
\text { wine tourism }\end{array}$ & $\begin{array}{l}\text { Domestic tourists } \\
\text { domestic: county + region + country (RO) } \\
\text { organised or non-organised form } \\
\text { young couples and families } \\
\text { elderly couples and smaller groups } \\
\text { they usually arrive by their own car } \\
\text { separate group: visiting relatives } \\
\text { The demand is defined by the date of the } \\
\text { gastro- and wine events of the region } \\
\text { (linked to event tourism) } \\
\text { They prefer traditional flavours. They are }\end{array}$ & $\begin{array}{l}\text { Domestic tourists } \\
\text { websites } \\
\text { Facebook page } \\
\text { tourist offices } \\
\text { gastronomy and wine } \\
\text { magazines (PR) } \\
\text { gastro-blogs (presenting } \\
\text { gastro experiences) } \\
\text { search engine keyword } \\
\text { optimisation (SEO) }\end{array}$ \\
\hline
\end{tabular}




\begin{tabular}{|c|c|c|}
\hline & $\begin{array}{l}\text { not real connoisseurs. In case of } \\
\text { organised gastro- or wine festivals, wine } \\
\text { round tours, they would spend several } \\
\text { days in the region. } \\
\text { Their accommodation is not necessarily } \\
\text { within the region. It depends on the } \\
\text { accommodation available at the location } \\
\text { of the event. }\end{array}$ & \\
\hline Ecotourism & $\begin{array}{l}\text { Domestic and foreign tourists } \\
\text { domestic: Transylvania and Romania } \\
\text { foreign: France, Germany, Spain, Italy, } \\
\text { United Kingdom, Hungary } \\
\text { not an organised form, young adults, } \\
\text { families, usually traveling by their own } \\
\text { car and with personal equipment } \\
\text { Adepts of a healthy lifestyle, seeking } \\
\text { active relaxation and environmentally } \\
\text { friendly tourism } \\
\text { They do not necessarily need } \\
\text { accommodation (camping). They usually } \\
\text { apply to auxiliary services (e.g. bike } \\
\text { rental). }\end{array}$ & $\begin{array}{l}\text { Domestic tourists } \\
\text { websites } \\
\text { Facebook pages } \\
\text { blogs, PR articles } \\
\text { search engine keyword } \\
\text { optimisation (SEO) } \\
\text { Foreign tourists } \\
\text { websites } \\
\text { Facebook pages } \\
\text { PR material (blogs and } \\
\text { online magazines) } \\
\text { search engine keyword } \\
\text { optimisation (SEO) }\end{array}$ \\
\hline $\begin{array}{l}\text { Health and spa } \\
\text { tourism }\end{array}$ & $\begin{array}{l}\text { Domestic tourism } \\
\text { domestic: county/Transylvania/Romania } \\
\text { families and young couples seeking } \\
\text { relaxation, middle age or elderly couples } \\
\text { seeking healing possibilities, individuals } \\
\text { needing therapy: not necessarily couples } \\
\text { (1-3 people) } \\
\text { It may be a form of relaxation for visiting } \\
\text { relatives; the spa may be appealing for } \\
\text { sick people living in the region and } \\
\text { needing therapy. } \\
\text { They usually travel to the region for a } \\
\text { longer time (for therapy), needing } \\
\text { accommodation and catering. } \\
\text { Their accommodation has to be close to } \\
\text { the spa. }\end{array}$ & $\begin{array}{l}\text { Domestic tourists } \\
\text { websites } \\
\text { Facebook pages } \\
\text { PR articles (news portals } \\
\text { and blog) } \\
\text { banner advertisements } \\
\text { (health sections of popular } \\
\text { news portals) } \\
\text { search engine keyword } \\
\text { optimisation (SEO) }\end{array}$ \\
\hline
\end{tabular}


Domestic and foreign tourism may have different forms (Table 7). There are round tours (within the region), day trips starting from the same point (tourists return to the same place at the end of the day), transit tourism (visitors spend only a short time in the region and usually do not spend the night there), static tourism which is characterised by tourists staying in the same place, and the proximity type of tourism when the place of accommodation is not within the studied region, but tourists visit the region day after day.

Table 7: Recommended tourist attractions and activities for different forms of tourism

\begin{tabular}{|c|c|c|}
\hline $\begin{array}{l}\text { Type of } \\
\text { tourism }\end{array}$ & Form of tourism & Recommendations \\
\hline \multirow{4}{*}{$\begin{array}{l}\text { Cultural and } \\
\text { heritage } \\
\text { tourism }\end{array}$} & \multirow[b]{2}{*}{ round tours } & $\begin{array}{l}\text { Castle roundtrips in the area: Carei (Károlyi), Nușfalău } \\
\text { (Bánffy), Jibou (Wesselényi) }\end{array}$ \\
\hline & & $\begin{array}{l}\text { Castle roundtrip in the area: Carei (Károlyi), Nușfalău } \\
\text { (Bánffy), Șimleu Silvaniei (Báthory), Treznea (Bay), } \\
\text { Coltău (Teleki) }\end{array}$ \\
\hline & \multirow[b]{2}{*}{ transit } & $\begin{array}{l}\text { Possible routes: Satu Mare, Carei, Nușfalău, Șimleu } \\
\text { Silvaniei, Crasna, Zalău, Jibou, Cluj-Napoca }\end{array}$ \\
\hline & & $\begin{array}{l}\text { Architectural heritage within the studied region: Bánffy } \\
\text { Castle and manor (Nulfalău), Reformed church } \\
\text { (Nușfalău, Crasna). }\end{array}$ \\
\hline \multirow{2}{*}{ Event tourism } & \multirow{2}{*}{$\begin{array}{l}\text { proximity or } \\
\text { static }\end{array}$} & $\begin{array}{l}\text { Accommodation: Șimleu Silvaniei or Zalău } \\
\text { Within the region: Boghiș } \\
\text { Highlighted events: Arany János Days (Nușfalău), Bánffy } \\
\text { György Days (Nușfalău), Pancake Festival (Marca) }\end{array}$ \\
\hline & & $\begin{array}{l}\text { Recommended events: Mushroom Festival (Nușfalău), } \\
\text { Honey Days (Valcău de Jos), fair of traditional local } \\
\text { products (Crasna, Nușfalău), Vintage Ball and Wine } \\
\text { Festival (Crasna) }\end{array}$ \\
\hline Rural tourism & static & $\begin{array}{l}\text { Highlighted settlements: laz, Marca, Boghiș } \\
\text { Activities: work around the house, work in the fields, } \\
\text { preparing food and drinks, locals presenting the making } \\
\text { process of traditional crafts in organized workshops }\end{array}$ \\
\hline \multirow{4}{*}{$\begin{array}{l}\text { Gastro- and } \\
\text { wine tourism }\end{array}$} & round tour & $\begin{array}{l}\text { Wine tasting round tour within the region: Crasna - } \\
\text { Vârșolț - Borla - Bocșa - Șărmășag - Carastelec - } \\
\text { Leșmir - Zăuan - Bilghez - Nușfalău - Boghiș } \\
\text { Visits to wine cellars in the region: Crasna - Nușfalău - } \\
\text { Bilghez - Leșmir - Zăuan }\end{array}$ \\
\hline & \multirow[t]{2}{*}{ static } & $\begin{array}{l}\text { Visiting gastro- and wine events in the area (e.g. Wine } \\
\text { Days, Wine Festival, Vintage Ball, Traditional Fair, } \\
\text { Pancake Festival, Mushroom Festival, Honey Days, etc.) }\end{array}$ \\
\hline & & $\begin{array}{l}\text { Accommodation in the region: Crasna, Nușfalău, Marca } \\
\text { (in local houses) }\end{array}$ \\
\hline & proximity & Accommodation: Șimleu Silvaniei, Zalău, Vârșolț \\
\hline
\end{tabular}




\begin{tabular}{|l|l|l|}
\hline & & $\begin{array}{l}\text { Visits to wine cellars: Bilghez, Crasna, Zăuan, Leșmir } \\
\text { Gastro events: honey (Valcău de Jos), mushroom } \\
\text { (Nușfalău), pancake (Marca) } \\
\text { Traditional fair: Crasna, Nușfalău }\end{array}$ \\
\hline Ecotourism & day trips & $\begin{array}{l}\text { Accommodation: Boghiș, laz, Nușfalău } \\
\text { Natural sites: laz wetland, Lapiș forest, oaktree } \\
\text { pastures, Vârșolț water reservoir, the Plopiș Mountains } \\
\text { Activities: hiking (study trails), nature photography, } \\
\text { fishing, horse riding, cycling }\end{array}$ \\
\hline $\begin{array}{l}\text { Health and spa } \\
\text { tourism }\end{array}$ & static & Health spa (Boghiș and Zăuan) \\
\hline
\end{tabular}

Source: Created by authors.

Tourism types may also be combined. Event tourism may offer new perspectives for cultural and heritage tourism. In this respect, the most important are the castles and manors of the region, not exploited properly at the moment. It is extremely important to renovate these historical buildings and restore their former beauty, and to fill them with life not only by organising events for the locals, but for visitors as well. Such events may be: wine tastings, dance performances, film projections, various exhibitions, etc. Castle visiting may be excellently paired with wine tourism, while these buildings may serve as a venue for wine events. Rural tourism can be associated quite well with gastro- and event tourism.

\section{SUPPORT FOR BRAND DEVELOPMENT AND STRENGTHENING}

This study defined the most valuable place identity elements of the examined region, including cultural and natural values as well, which can serve as brand pillars for future place branding and especially destination branding projects for the area. The first part of the paper presented these potential brand elements, including architectural heritage, natural heritage, famous personalities, local gastronomy, local events, as well as folk traditions. The following section highlighted the most critical elements that are currently impeding the efficient exploitation of these potential values. The next part analysed the current situation of tourism within the region, providing a list of the accommodations and catering facilities currently available in the area, of tourist information offices and of other elements belonging to the tourist infrastructure (i.e. ethnographic museums, traditional houses, fish ponds, riding facilities). It also presented the types of tourism directions that might have had potential within the region, outlining the current situation and the future recommendations. A total of six types of tourism were identified as suitable for the studied region, including cultural and heritage tourism, event tourism, rural tourism, gastro- and wine tourism, ecotourism, and finally health and wellness tourism. Based on the above mentioned tourism types, we developed a plan consisting of the key target groups for each type of tourism and the recommended communication channels for each domestic and foreign target group. Finally, we assigned possible tourism forms for each tourism types, including transit, round travels, day trips, proximity, and static forms as well. 
In order to emphasise the branding pillars and exploit them for tourism purposes, the studied region requires well-defined, strategically designed communication. Without laying down the tracks for a branding plan, here are some concerns and recommendations based on the presented data:

1. As far as communication channels are concerned, online presence needs more emphasis and should be better synchronised. At the moment, certain settlements do not have an official website and some of them have no Tourist Information Offices at all. The region should pay more attention to the development of these online channels. In order to address a wider public, these channels should be accessible in more languages (i.e. Romanian, Hungarian and English).

2. To promote the region, it is recommended that local administrations acting as brand owners start developing partnerships and establish a DMO (Destination Management Organisation) responsible for the coherent communication of the area. The DMO should have its online and offline communication channels with a properly defined tourism brand identity. One possible message presenting the region for visitors could be "Western Gate of Transylvania", connecting it to a wider known region, calling for explorers to discover even more.

3. Based on our research and the available statistical data, we can conclude that the examined region is underdeveloped in terms of tourism infrastructure. The region, on the other hand, would greatly benefit from a much more powerful presence within the touristic promotion of Sălaj County or Sălaj region in general. The current promotion materials and development plans have no focus on this area.

4. In order to gain more visitors, local and regional organisations responsible for tourism promotion should provide offers for regional round tours that include the settlements from the studied region as well. As our research highlighted, certain natural and cultural values can be exploited more efficiently. Some identified possible directions would be the heritage tourism (castle round trips) and the wine tourism (wine tasting trips), considering the offers of similar regions in Western Romania and Eastern Hungary.

5. The opportunities offered by rural and health tourism should be exploited more efficiently in order to pursue visitors to spend more nights in the region. Moreover, in order to benefit more from the potential local values, one possible direction is the organisation of local events that can generate overnight stays from visitors. Events promoting the local traditions and gastronomic festivals should be considered in this regard. The synchronization of these local events could be a good opportunity to keep the tourists and visitors in the area, for a longer period of time.

\section{Acknowledgements}

Study developed within the project "Culture and Nature in Transylvania: Past and Future" („Cultură şi Natură în Transilvania: Trecut şi Viitor”), PA16 / RO12-SGS-84 / 28.04.2014, conducted by the Hungarian University Federation of Cluj (FUMC - KMEI), funded by PA16 / RO12 "Conservation and Revitalization of Cultural and Natural Heritage" - Small Grants Scheme, funded by the EEA Financial mechanism 2009-2014, by the Ministry of Culture. The members of the communication expert team were dr. habil. Kádár Magor (coord.), Benedek István, Ph.D. student, Makkai Júlia, Ph.D. student, and Péter Andrea, all from the academic community of Babeș-Bolyai University, Cluj Napoca, Romania. 


\section{REFERENCES}

AGENTIA DE DEZVOLTARE REGIONALA NORD-VEST [NORTH-WEST REGIONAL DEVELOPMENT OFFICE] (2014). Planul de Dezvoltare al Regiunii Nord-Vest 2014-2020 [Development Plan of the North-West Region for 20142020]. Retrieved 21 August 2018, from http://www.nord-vest.ro/wpcontent/uploads/2016/09/7r238_PDR_2014_2020.pdf

ANHOLT, S. (2010). Definitions of Place Branding - Working towards a Resolution. Place Branding and Public Diplomacy, 6(1), 1-10.

BENEDEK, I. (2017). Helymárkázás: Értelmezések, alapfogalmak és aktuális nézetek. [Place Branding: Interpretations, Basic Concepts and Current Trends]. Pro Minoritate, 4, 39-47.

BOISEN, M. (2015). Place Branding and Non-Standard Regionalization in Europe. In: ZENKER, S. \& JACOBSEN, B.P. (eds.), Inter-regional Place Branding: Best Practices, Challenges and Solutions. Cham: Springer International.

BRAUN, E. (2011). Putting City Branding into Practice. Place Branding and Public Diplomacy, 13(1), 1-3.

BRICIU, V.A. (2013). Differences between Place Branding and Destination Branding for Local Brand Strategy Development. Bulletin of the Transylvania of Brasov, Series VII: Social Sciences and Law, 6(55)(1), 9-14.

BUJDOSÓ, Z., KEREKESNÉ-MAYER, Á., \& UJVÁRI, Z. (2012). Gasztronómia a vendéglátásban. [Gastronomy in Hospitality]. Károly Róbert Főiskola, Budapest, Retrieved 21 August 2018, from: http://www.tankonyvtar.hu/en/tartalom/tamop412A/20100010_12_Gasztronomia_a_vendeglatasban/adatok.html

CSIZMADIA, L. (1993). Falusi turizmus - környezetbarát turizmus oktatási összefüggései. [Rural Tourism Educational Contexts of Environmentally Friendly Tourism]. In: KOVÁCS, D. (ed.), A falusi turizmus hagyományai [Traditions of Rural Tourism] (pp. 69-73). Budapest: Mezőgazda Kiadó.

GETZ, D. (2008). Event Tourism: Definition, Evolution, and Research. Tourism Management, 29(3), $403-428$. Retrieved 20 April 2017, from: http://doi.org/10.1016/j.tourman.2007.07.017

GOVERS, R., \& GO, F.M. (2009). Place Branding: Glocal, Virtual and Physical Identities, Constructed, Imagined and Experienced. Basingstoke: Palgrave MacMillan.

GOVERS, R., KAEFER, F., \& FERRER-ROCA, N. (2017). The State of Academic Place Branding Research according to Practitioners. Place Branding and Public Diplomacy, 13(1), 1-3.

HANKINSON, G. (2015). Rethinking the Place Branding Construct. In: KAVARATZIS, M., WARNABY, G. \& ASHWORTH, G.J. (eds.), Rethinking Place Branding. Comprehensive Brand Development for Cities and Regions. Cham: Springer International.

KÁDÁR, M. (2013). Arculatépítés a városmárkázásban. Erdélyi városok márkázásának tapasztalatai [Identity Building in City Branding. Experiences from Transylvanian Towns]. Korunk, 24(4), 44-49.

KÁDÁR, M. (2016). Media Image Analysis of the Western Region of Sălaj County. Journal of Media Research, 9(3), 78-95. Retrieved 21 August 2018, from: http://www.mrjournal.ro/docs/R2/26MR0.pdf

KLADOU, S., KAVARATZIS, M., RIGOPOULOU, I., \& SALONIKA, E. (2017). The Role of Brand Elements in Destination Branding. Journal of Destination Marketing \& Management, 6(4), 426-435.

KOVÁCS, ZS., MARKÓ, B., MOLNÁR-KOVÁCS, ZS., SZABÓ, Á.T., \& KÁDÁR, M. (2016). Culture and Nature in Transylvania. Propunere strategică pentru un management integrat și performant al valorilor de patrimoniu cultural și natural. Project working paper: Conservarea și Revitalizarea Patrimoniului Cultural și Natural. Hungarian University Federation from Cluj-Napoca [Culture and Nature in Transylvania. Strategic Proposal for Integrated Management of Cultural and Natural Heritage. Project Working Paper: Conservation and Revitalization of Cultural and Natural Heritage] (HUFC - FUMC), Grant EEA PA16/RO12, 2016.

MARKÓ, B., SZABÓ, Á.T., KOVÁCS, ZS., MOLNÁR-KOVÁCS, ZS., SZALMA, A., \& MAKKAI, J.A. (2016). Kultúra, Természet, Örökség: A kulturális és a természeti örökség kapcsolatának multidiszciplináris vizsgálata Dél-NyugatSzilágyságban [Culture, Nature, Heritage: The Multidisciplinary Analysis of Cultural and Natural Heritage in the South-West Part of Sălaj Region]. In: JAKAB, A.ZS. \& VAJDA, A. (eds.), Érték és közösség. A hagyomány és az örökség szerepe a változó lokális regiszterekben [Values and Communities. The Role of Traditions and Heritage in Changing Local Registers] (pp. 101-129). Cluj-Napoca: Kriza János Néprajzi Társaság. 
MAYES, R. (2008). A Place in the Sun: The Politics of Place, Identity and Branding. Place Branding and Public Diplomacy, 4(2), 124-132.

MICHALKÓ, G. (2004). A turizmuselmélet alapjai [The Basics of Tourism Theory]. Budapest: Kodolányi János Főiskola.

MICHALKÓ, G., \& RÁTZ, T. (2005). A kulturális turizmus élmény-gazdaságtani szempontjai [The Economic and Experience Aspects of Cultural Tourism]. Budapest: Magyar Tudományos Akadémia Földrajztudományi Kutató Intézet.

MINISTERUL TURISMULUI [NATIONAL AUTHORITY FOR TOURISM] (2018). Structurile de primire turistice cu funcțiuni de cazare clasificate [Classified Tourist Accommodation Structures]. Retrieved 21 August 2018, from http://turism.gov.ro/web/autorizare-turism/

Strategia de dezvoltare a județului Sălaj 2014-2020 [Development Strategy of Sălaj County 2014-2020]. Retrieved 23 April 2016, from http://www.cjsălaj.ro/pdf/Strategia\%20pentru\%20dezvoltarea\%20durabila\%20a\%20judetu lui\%20Sălaj\%202014-2020.pdf

Strategia de dezvoltare locală pentru perioada 2014 - 2020 a unității administrative-teritoriale Nușfalău, județul Sălaj [Local Development Strategy for 2014-2020 of the Nușfalău Territory, Sălaj County]. Retrieved 23 April 2016, from https://www.nusfalau.ro/atasamente/documente/431/Strategia\%20de\%20dezvoltare\%20locala \%202014-2020\%20a\%20comunei\%20\%20\%20Nusfalau\%20completata-VARIANTA\%20FINALA.pdf

SWARBROOKE, J. (1994). The Future of the Past: Heritage Tourism into the 21st Century. In: SEATON, A.V. (ed.), Tourism: The State of the Art (pp. 222-229). Chichester: Wiley.

TASNÁDI, J. (2002). A turizmus rendszere [The System of Tourism]. Budapest: Aula Kiadó KFT.

ZENKER, S., \& BRAUN, E. (2010). Branding a City: A Conceptual Approach for Place Branding and Place Brand Management. $39^{\text {th }}$ European Marketing Academy Conference, Copenhagen, 1-4 June. 